
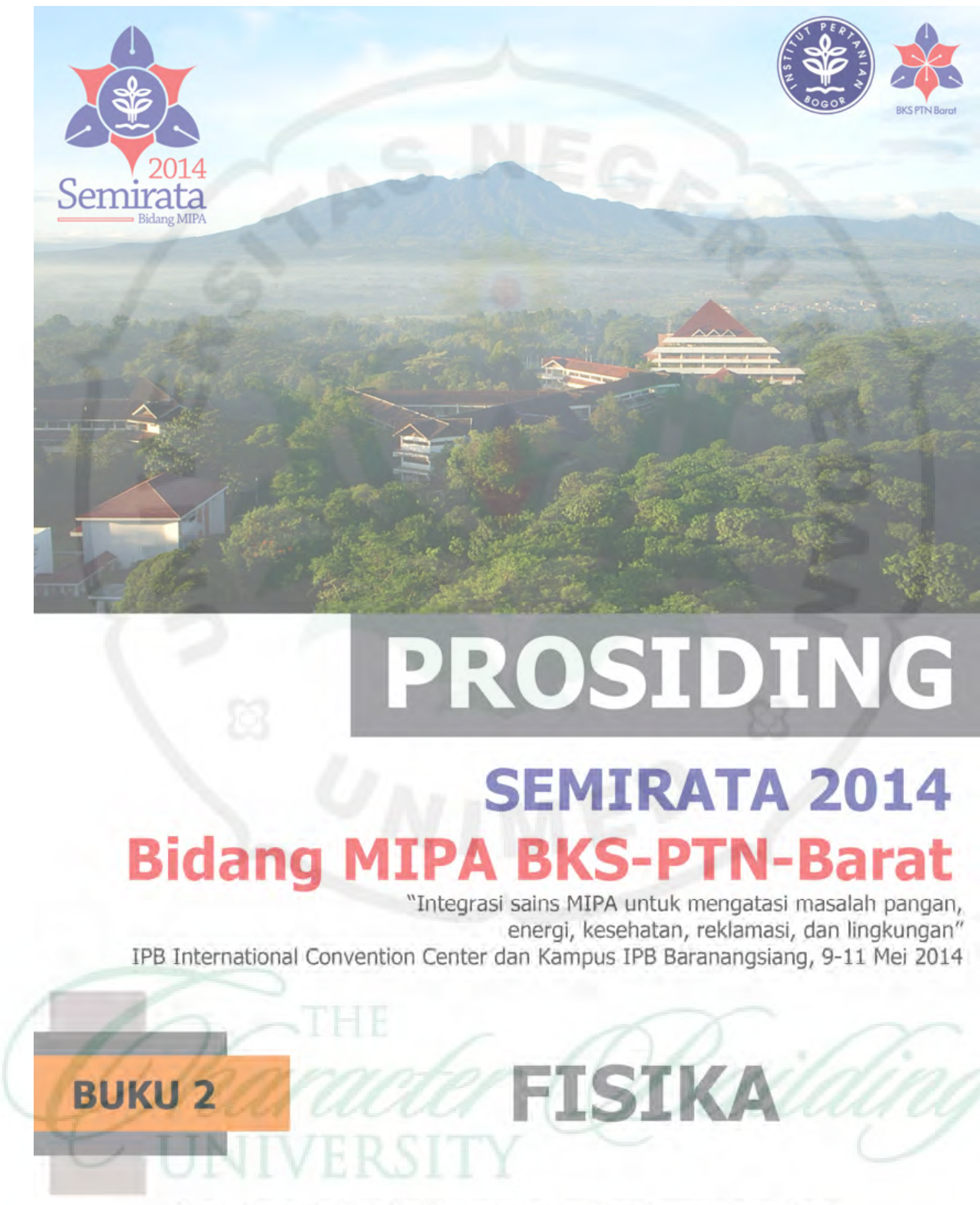

Diterbitkan oleh: Fakultas Matematika dan Ilmu Pengetahuan Alam Institut Pertanian Bogor

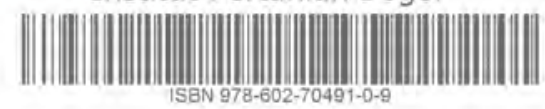




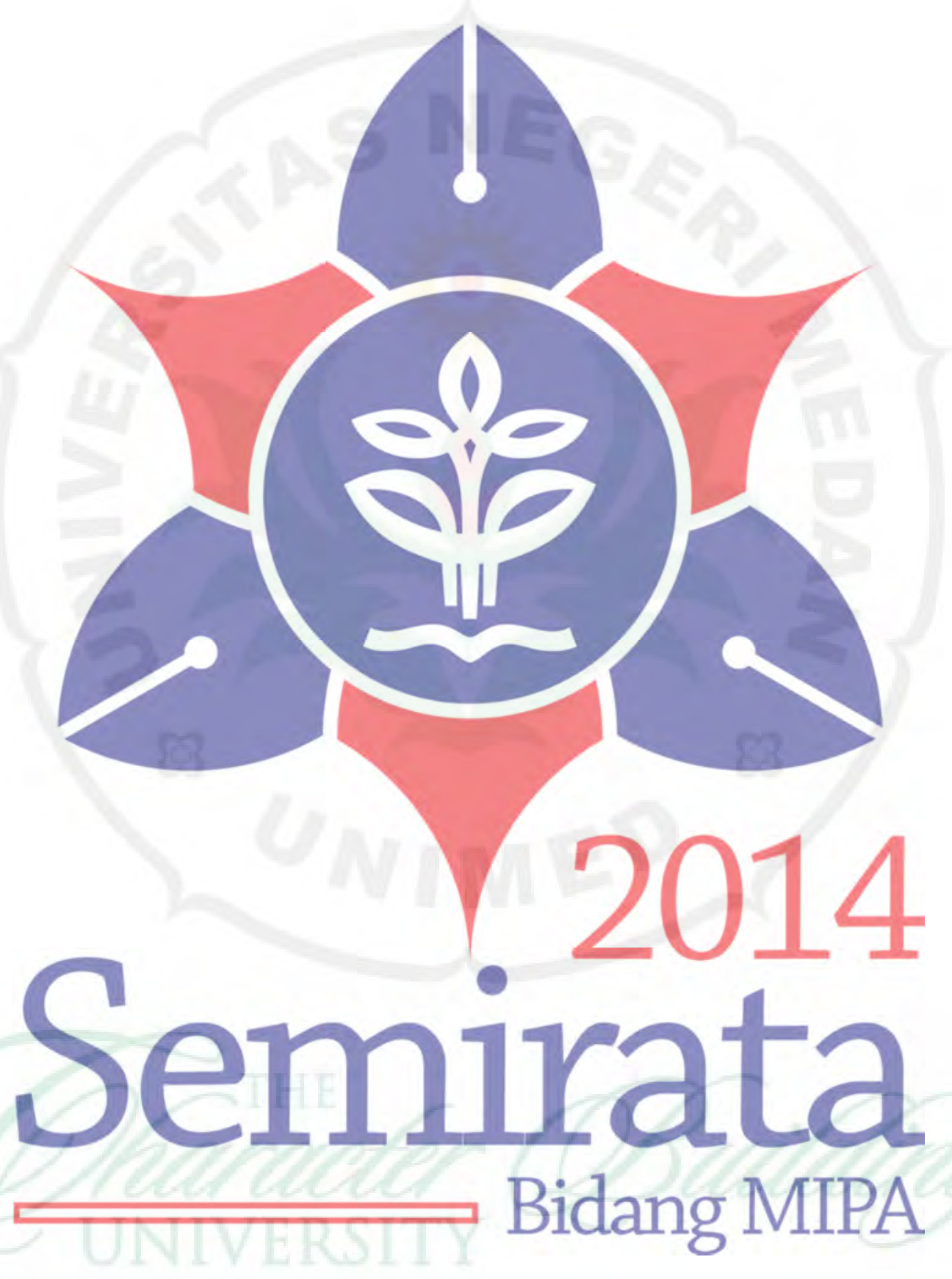


Seminar Nasional dan Rapat Tahunan Bidang M IPA 2014 | SEMI RATA

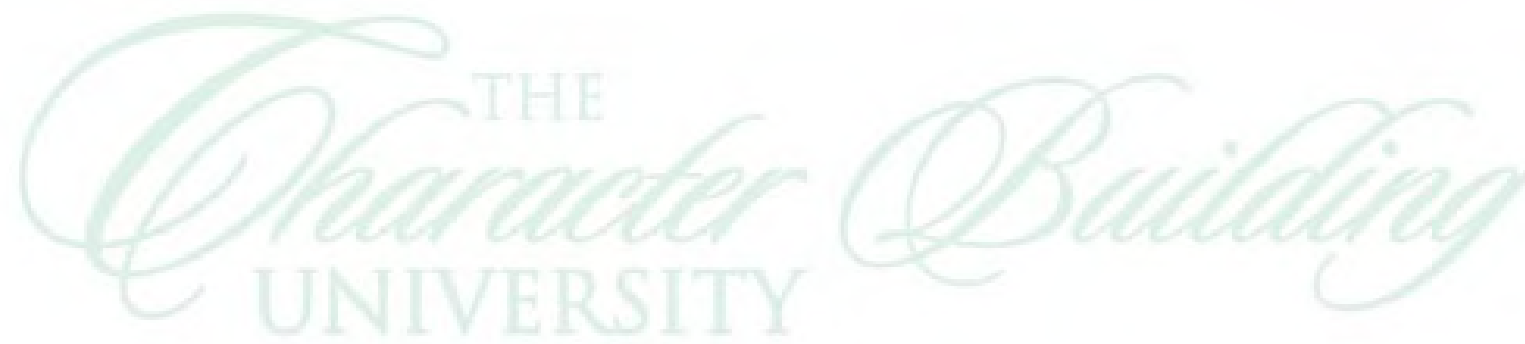




\section{ISBN : 978-602-70491-0-9}

\section{PROSIDING}

\section{Seminar Nasional dan Rapat Tahunan Bidang MIPA 2014}

"Integrasi Sains MIPA untuk Mengatasi Masalah Pangan, Energi, Kesehatan, Lingkungan, dan Reklamasi"

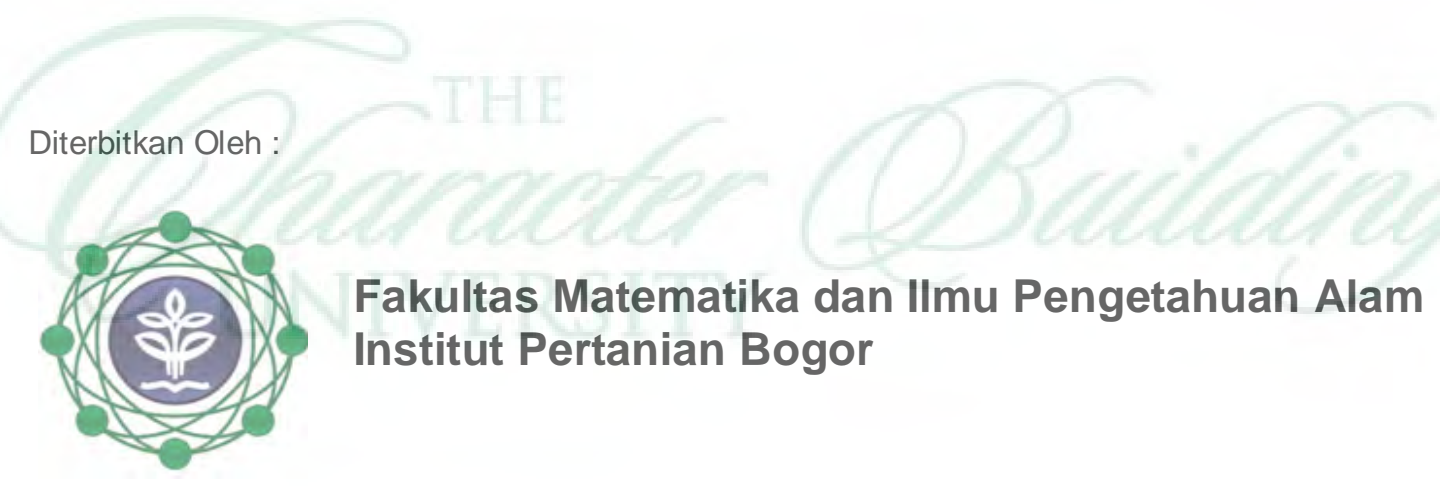


Copyright(C) 2014

Fakultas Matematika dan Ilmu Pengetahuan Alam, Institut Pertanian Bogor

Prosiding Seminar Nasional dan Rapat Tahunan Bidang MIPA 2014, 9-11 Mei 2014

Diterbitkan oleh : FMIPA-IPB, Jalan Meranti Kampus IPB Dramaga, Bogor 16680

Telp/Fax: 0251-8625481/8625708

http://fmipa.ipb.ac.id

Terbit Oktober, 2014

ix +632 halaman

ISBN: 978-602-70491-0-9 


\section{Editor dan Reviewer}

\section{PROSIDING \\ Seminar Nasional dan Rapat Tahunan Bidang MIPA 2014}

\section{Direktor Editor}

- Drs. Ali Kusnanto, MSi.

- Dr. Heru Sukoco

- Dr. Wisnu Ananta Kusuma

- Dr. Imas Sukaesih Sitanggang

- Auzi Asfarian, M.Kom

- Wulandari, S.Komp

- Dean Apriana Ramadhan, S.Komp

\section{Editor Utama}

- Dr. Rika Raffiudin

- Dr. Ence Darmo Jaya Supena

- Dr. Utut Widyastuti

- Prof. Dr. Purwantiningsih

- Dr. Tony Ibnu Sumaryada

- Dr. Imas Sukaesih Sitanggang

- Dr. Wisnu Ananta Kusuma

- Dr. drh. Sulistyani, MSc.

- Dr. Indahwati

- Dr. Sobri Effendi

- Drs. Ali Kusnanto, MSi.

\section{Editor Pembantu}

- Sodik Kirono

\section{Reviewer}

- Dr. Tony Ibnu Sumaryada, M.Si

- Dr.Ir. Irzaman, M.Si

- Drs. Mohammad Nur Indro, M.Sc

- Dr. Jajang Juansyah, M.Si

- Dr. Husin Alatas, M.Si

- Dr.Ir. Irmansyah, M.Si 


\section{KATA PENGANTAR}

Kegiatan Seminar dan Rapat Tahunan Bidang MIPA tahun 2014 (Semirata-2014 Bidang MIPA) Badan Kerja Sama Perguruan Tinggi Negeri Wilayah Barat (BKS-PTN Barat) yang diamanahkan kepada FMIPA-IPB sebagai penyelenggara telah dilaksanakan dengan sukses pada tanggal 9-11 Mei 2014 di IPB International Convention Center dan Kampus IPB Baranagsiang, Bogor. Salah satu program utama adalah Seminar Nasional Sains dan Pendidikan MIPA dengan tema: "Integrasi sains MIPA untuk mengatasi masalah pangan, energi, kesehatan, dan lingkungan".

Dalam sesi pleno seminar telah disampaikan pemaparan materi oleh satu pembicara utama dan empat pembicara undangan yang berasal dari beragam institusi dan profesi. Dari sesi pleno ini, diharapkan peserta dapat menambah wawasan dan pemahaman tentang pengembangan dan pemanfatan IPTEK, khususnya Bidang MIPA, sehingga sains dan pendidikan MIPA terus berkembang dan dapat berkontribusi nyata untuk kemajuan dan kemakmuran bangsa Indonesia.

Kegiatan yang tidak kalah pentingnya dalam seminar ini adalah sesi paralel karena telah memberi kesempatan kepada peserta untuk melakukan presentasi dan komunikasi ilmiah secara langsung dengan sesama kolega yang mempunyai minat yang sama dalam mengembangkan Sains dan atau Pendidikan MIPA. Dalam kegiatan sesi paralel ini dipresentasikan secara oral 592 judul makalah hasil penelitian yang disampaikan dalam 37 ruang seminar secara paralel, dan juga dipresentasikan 120 poster ilmiah. Dalam kegiatan komunikasi ilmiah secara langsung ini juga telah dimanfaatkan untuk menjalin jejaring agar lebih bersinergi dalam pengembangan Sains dan Pendidikan MIPA ke depannya. Supaya komunikasi ilmiah yang baik ini dapat juga tersampaikan ke komunitas ilmiah lain yang tidak dapat hadir pada kegiatan seminar, panitia memfasilitasi untuk menerbitkan makalah dalam bentuk Prosiding. Panitia juga tetap memberi kesempatan kepada peserta yang akan menerbitkan makalahnya di jurnal ilmiah, sehingga tidak seluruh materi yang disampaikan pada seminar diterbitkan dalam prosiding ini.

Dalam proses penerbitan prosiding ini, panitia telah banyak dibantu oleh Tim Reviewer dan Tim Editor yang dikoordinir oleh Ali Kusnanto yang telah dengan sangat intensif mencurahkan waktu, tenaga dan pikiran. Untuk itu, panitia menyampaikan terima kasih dan penghargaan. Panitia juga menyampaikan terima kasih dan penghargaan kepada seluruh penulis makalah yang telah merespon dengan baik hasil review artikelnya. Namun, panitia juga menyampaikan permohonan ma' af karena dengan sangat banyaknya makalah yang akan diterbitkan dalam prosiding ini, waktu yang dibutuhkan dalam proses penerbitan prosiding ini mencapai lebih dari empat bulan, dan penerbitan prosiding tidak dilakukan dalam satu buku tetapi dalam tujuh buku prosiding. Semoga penerbitan prosiding ini selain bermanfaat bagi para pemakalah dan penulis, juga dapat bermanfaat dalam pengembangan Sains dan Pendidikan MIPA.

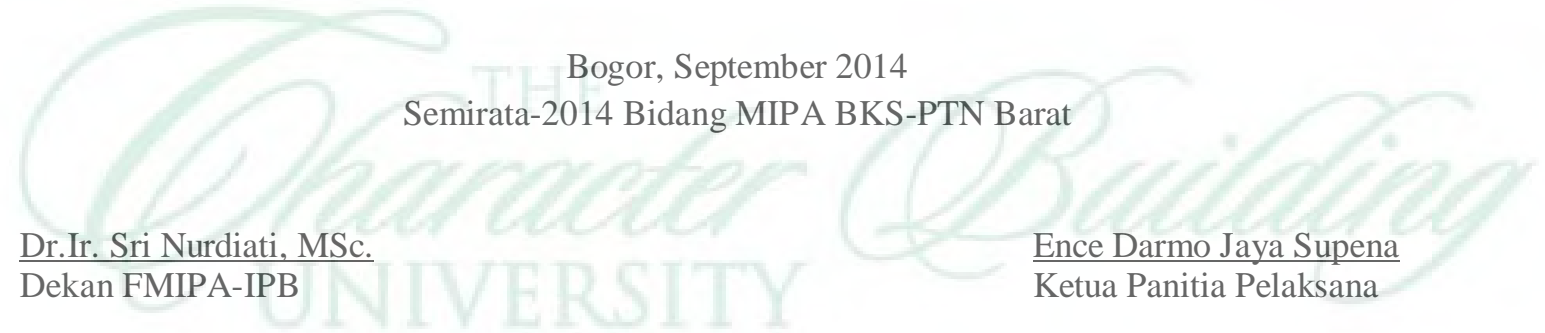




\section{Daftar Isi}

Halaman

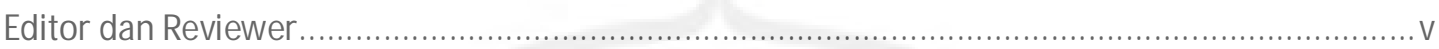

Daftar Isi .............................................................................................................. vii

UJI SENSITIVITAS M INYAK GORENG TERHADAP TEM PERATUR BERDASARKAN SIFAT OPTIK DAN MAGNETIK

A.Aminudin, Waslaluddin, A.Danawan 15

SPEKTROSKOPI IM PEDANSI ELEKTROKIM IA SEL SUPERKAPASITOR DARI CAM PURAN PRAKARBONISASI SERABUT TANDAN KOSONG KELAPA SAWIT DAN GREEN PETROLEUM COKE

Awitdrus, Mohamad Deraman, Rakhmawati Farma.......................................................... 22

ANALISIS SIFAT OPTIK DAN STRUKTUR LAPISAN TIO ${ }_{2}$ YANG DIHASILKAN DARI BEBERAPA VARIASI ELEKTRODEPOSISI

Dahyunir Dahlan and lin Lidia Putama M .32

ELEKTRODA KOM POSIT KARBON AKTIF DARI KULIT UBI KAYU-KARBON NANO TUBE-POLIANELIN UNTUK APLIKASI SUPERKAPASITOR

Erman Taer, Satri, Rika Taslim, Iwantono.

ANALISIS ENERGI BAND GAP PADA FILM TIPIS Ba $\mathrm{Ba}_{0.55} \mathrm{Sr}_{0.45} \mathrm{TiO}_{3}$ DI ATAS SUBSTRAT SILIKON (100) TIPE-P

Hadyan Akbar, Nurhasanah, Maimuna, Hisyam, Irzaman 47

PERBANDINGAN KINERJA M ETODE JACOBI PARALEL DENGAN INTEL TBB DAN OPENM P UNTUK PENYELESAIAN PERSAM AAN DIFUSI NEUTRON

Imam Taufiq

KONTRIBUSI FAKTOR-FAKTOR LINGKUNGAN UNTUK AKUIFER BEBAS KONDISI UNSTEADY STATE

Juandi. M

ANALISIS ENERGI TERM AL DARI TUNGKU BERBAHAN BAKAR BAGLOG JAM UR TIRAM, SEKAM PADI DAN CAM PURAN 50\% MASSA BAGLOG JAM UR TIRAM DENGAN 50\% MASSA SEKAM PADI

Kharis M awan Suhaeli , Nofitri , Ryan Sugihakim , Setiawan Hari Santoso , Habiburahmat Yulwan, Irzaman

DINAMIKA UPWELLING DI PERAIRAN SELATAN JAWA TIMUR

Liza Lidiawati, Safwan Hadi, M utiara R. Putri, Nining Sari Ningsih .78

RANCANG BANGUN SPEKTROM ETER ABSORPSI TERSATURASI UNTUK ANALISA SPEKTRUM ATOM RUBIDIUM

M inarni, Habi Rizkana ..... .89

PENENTUAN ULANG KUM PULAN NILAI KOEFISIEN UNTUK M ENGHITUNG SUHU UDARA HARIAN DATA KLIMATOLOGI KOTA PALEM BANG 
Octavianus Cakra Satya, Arsali, Isti Hamiyatun, S.T., Bambang Benny Setiaji, S.Kom. .98

PENGARUH LARUTAN ELEKTROLIT TERHADAP PERFORM A SEL SUPERKAPASITOR

Rakhmawati Farma, Mohamad Deraman, Awitdrus. 104

PEM ODELAN IKATAN KIM IA PADA BAGLOG MISELIUM DAN JAMUR TIRAM M ENGGUNAKAN KONSTANTA PEGAS DAN FREKUENSI VIBRASI

Rey Fariz Irwansyah, Rofiqul U mam, Nofitri, M aya Risantis, Irzaman, Irmansyah 114 KAIIAN KONSTANTA PEGAS SERTA FREKUENSI VIBRASI BAGLOG M ISELIUM DAN JAMUR TIRAM PUTIH MENGGUNAKAN METODE FOURIER TRANSFORM INFRA RED (FTIR)

Rofiqul Umam, Rey Fariz Irwansyah, Nofitri, Maya Risanti, Ardian Arif, Irzaman .... 123 ANALISIS KUALITAS BATUBARA BERDASARKAN KANDUNGAN LOGAM BERAT, NILAI HGI DAN NILAI KALORI

Sri Handani, Aisyah Amin, Astuti 134

PENGARUH WAKTU AKTIVASI TERHADAP SIFAT FISIS KARBON AKTIF BERBASIS ARANG TEM PURUNG KEM IRI (Aleurites moluccana)

Sri Mulyadi Dt. Basa, Astuti, Anggun Pradilla Sandi. 140 PEM BUATAN SUPERKONDUKTOR SUHU TINGGI TI ${ }_{2-x} \mathrm{Cr}_{x} \mathrm{Ba}_{2} \mathrm{CaCu}_{2} \mathrm{O}_{8-\delta}$ (TI-2212) DENGAN REAKSI STOIKIOMETRI

Syahrul Humaidi, Eddy M arlianto, M arhaposan S dan Roslan Abd-Shukor 146 PENGARUH LARUTAN ELEKTROLIT TERHADAP PERFORM A SEL SUPERKAPASITOR

Rakhmawati Farma, Mohamad Deraman, Awitdrus. Error! Bookmark not defined. EFEK ADITIF FRIT GELAS TERHADAP KARAKTERISTIK DIELEKTRIK KAPASITOR KERAMIK FILM TEBAL $\mathrm{BATIO}_{3}$

Walfred Tambunan 153

PENGEM BANGAN ALAT UKUR CURAH HUJAN BERBASIS KONSEP BERAT M ENGGUNAKAN SENSOR FLEXIFORCE TIPE A201-25

Zulhendri Kamus, Dwi Sativa Putri..... 163 M ODIFIKASI PERM UKAAN KARBON AKTIF M ONOLIT DARI SERBUK GERGAJI KAYU KARET DENGAN ZnO NANO PARTIKEL UNTUK ELEKTRODA SUPERKAPASITOR

Erman Taer dan Rika Taslim

PENGEM BANGAN MODEL VIRTUAL CLASSROOM FISIKA DAN PERANNYA SEBAGAI “GURU"

Afrizal Mayub. 182

PEM BELAJARAN IPA BERBASIS PENGAM ATAN M ELALUI PENDEKATAN ILM IAH DI SEKOLAH MENENGAH ATAS

Amali Putra. 190

IM PLEM ENTASI M ODEL PROBLEM BASED LEARNING BERBANTUAN M EDIA SEBAGAI UPAYA MENINGKATKAN KEM AM PUAN BERFIKIR LOGIS SISWA SMA KOTA BENGKULU

viii 
Andik Purwanto 200

HASIL VALIDASI BAHAN AJAR ICT SAINS TERPADU M ODEL TERHUBUNG M ENGINTEGRASIKAN NILAI KARAKTER UNTUK PEM BELAJ ARAN SISWA SM P KELAS VIII

Asrizal, Ramadhan Sumarmin, Iswendi, dan Trisya Gustiya 209

PELAKSANAAN REM EDIAL TEACHING DALAM MENCAPAI KETUNTASAN BELAJAR SISWA PADA MATA PELAJARAN FISIKA DI SM A NEGERI SE-KOTA PEKANBARU

Azhar, Azizahwati \& Resiana Heri Agusti 219

PENGARUH MODEL PEM BELAJARAN DAN TINGKAT KEM AM PUAN BERPIKIR TERHADAP HASIL BELAJAR FISIKA SISWA SM A NEGERI 3 M EDAN

Derlina ...... .231

IM PROVING THE STUDENT'S ABILITY TO ANALIZE THE ENVIRONM ENT PROBLEM S BY STAD AND COM PREHENSION ABOUT LIMITING FACTOR IN THE ENVIRONM ENT

Desnita, Nadiroh, Suwirman N, 241

PEM BELAJARAN FISIKA TOPIK LISTRIK DENGAN M ENGGUNAKAN M ODEL PEM BELAJARAN PROBLEM SOLVING PADA M AHASISWA PENDIDIKAN FISIKA UNTUK M ENINGKATKAN PEM AHAM AN KONSEP DAN KEM AM PUAN PROBLEM SOLVING FISIKA

Eko Swistoro Warimun .252

PENGEM BANGAN ALAT PERCOBAAN PESAWAT SEDERHANA BERBASIS PERALATAN BUDAYA TRADISIONAL PADA MATA PELAJARAN IPA FISIKA SM P

Fakhruddin. Z, Lilia Halim, T. Subahan M ohd. Meerah, Hendar S, Fenni M arriza. .260 PENGINTEGRASIAN KARAKTER HEM AT ENERGI KE DALAM MATERI FISIKA SM A M ENGGUNAKAN CONCEPTS FITTING TECHNIQUE

Hamdi Rifai, Ahmad Fauzi, Yulkifli Amir 269

PENGEM BANGAN DAN VALIDASI FORCE CONCEPT INVENTORY UNTUK M ENGIDENTIFIKASI PEM AHAM AN M AHASISWA TERHADAP KONSEP GAYA

Irwan Koto .277

PENINGKATAN PENGUASAAN PENGETAHUAN KONSEPTUAL DAN PROSEDURAL M ELALUI PENERAPAN STRATEGI PEM BELAJARAN PROBLEM SOLVING PADA MATA KULIAH GELOMBANG

Iwan Setiawan, Eko Swistoro .286

CONFIRM ATORY FACTOR ANALYSIS (CFA) DALAM PENGEMBANGAN DAN PENYEM PURNAAN INSTRUM EN PPEC

Maison .293

MENINGKATKAN SIKAP ILM IAH PADA MAHASISWA M ELALUI PENGGUNAAN M ODUL PENGETAHUAN LINGKUNGAN BERBASIS INKUIRI

Misbahul Jannah, Lilia Halim, Fitriyawany, M uchlis. .297 
PERANCANGAN DAN PEMBANGUNAN PROGRAM ANALISIS BUTIR SOAL UJIAN AKHIR SEM ESTER DALAM RANGKA MENGHASILKAN SOAL YANG BAIK DAN BERMUTU SEBAGAI ALAT EVALUASI PEM BELAJARAN FISIKA

Muhammad Nasir 306

HASIL BELAJ AR KOGNITIF FISIKA M AHASISWA M ELALUI PENERAPAN M ODEL PEM BELAJARAN PROBLEM POSING DI PROGRAM STUDI PENDIDIKAN FISIKA PADA MATERI GERAK ROTASI DAN GERAK PERIODIK

Muhammad Nor, Fakhruddin. Z

PENGEM BANGAN M EDIA PEM BELAJARAN BERBASIS WEB M ENGGUNAKAN JOOM LA PADA MATA KULIAH FISIKA BUMI DAN ANTARIKSA

Nova Susanti , Astalini. 327

PEM BUATAN BAHAN AJAR M ENGGUNAKAN FLIP BOOK M AKER PADA M ATERI TEORI RELATIVITAS KHUSUS

Nova Susanti, S. Pd, M. Si, Sri Purwaningsih, S. Si., M. Si, Dra. Jufrida, M. Si 336

FRAM EWORK EVALUASI KUALITAS APLIKASI M OBILE E-LEARNING

Pakhrur Razi , Amali Putra 344

SIKAP DAN PANDANGAN M AHASISWA TERHADAP PEM BELAJARAN FISIKA UMUM I BERBASIS ARGUM ENTASI ILM IAH DALAM MENINGKATKAN PEMAHAMAN KONSEP

Pintor Simamora, Sondang Manurung, Juniastel Rajagukguk. 353

PROFIL PENALARAN ILMIAH (Scientific Reasoning) M AHASISWA PROGRAM STUDI PENDIDIKAN FISIKA UNIVERSITAS BENGKULU TAHUN AKADEM IK 2013/2014

Sutarno 361

DESAIN BAHAN AJAR BERNILAI KARAKTER PADA M ATERI FISIKA SM A

Yenni Darvina, Masril 372

UPAYA INTERNALISASI SCIENTIFIC ATTITUDE M AHASISWA M ELALUI INDUCTIVE TEACHING M ETHODSADA M ATAKULIAH PRAKTIKUM FISIKA DASAR DI PROGRAM STUDI PENDIDKAN BIOLOGI PMIPA FKIP UR

Zulhelmi, M Nur 380

PENGEM BANGAN BAHAN AJAR BERBASIS ADVANCE ORGANIZER UNTUK MATA PELAJARAN FISIKA SM A

Masril, Hidayati 390

MODEL PEM ECAHAN MASALAH FISIKA MENGGUNAKAN PROBLEM BASED LEARNING BERBANTUAN SOLUTION PATH OUTLINE UNTUK M ENINGKATKAN KETERAM PILAN DAN KARAKTER BERPIKIR KRITIS SISWA SM A

Djusmaini Djamas, Zulhendri Kamus. 399

PENGEM BANGAN M ATAKULIAH FISIKA DASAR 2 DI IPB M ENGGUNAKAN FORM AT SEMI FISIKA STUDIO 
PENGARUH KONSENTRASI ZAT PENCEM AR TERHADAP RESISTIVITAS AIR TANAH

Afdal, Srinandi. 419

PENGARUH TEM PERATUR TERHADAP NILAI KONDUKTIVITAS LISTRIK ZEOLIT DARI LIM BAH BOTTOM ASH

Afdhal Muttaqin H.S., Hendra M ustika, Emriadi 428

ANALISIS BIDANG GELINCIR M ENGGUNAKAN M ETODA INVERSI MARQUARDT TERBOBOT DATA GEOLISTRIK KONFIGURASI SCHLUM BERGER DI DESA KAM PUNG MANGGIS KECAM ATAN PADANG PANJANG BARAT

Akmam, Nofi Yendri Sudiar, Lismalini, Herawati 433

ANALSIS SIFAT FISIS DAN M EKANIK PAPAN KOM POSIT GIPSUM SERAT IJUK DENGAN PENAM BAHAN BORAKS (Dinatrium Tetraborat Decahydrate)

Alimin Mahyudin, Hilda Trisna..... 444

HOM EWORK SHEETS BERBASIS M OODLE E_ LEARNING FOR SRIWIJAYA STUDENT (M ODELSS) MATA KULIAH FISIKA DASAR I MATERI M EKANIKA M AHASISWA TINGKAT I JURUSAN PMIPA FKIP UNIVERSITAS SRIWIJAYA

Apit Fathurohman

ANALISIS KONDUKTIVITAS LISTRIK M ATA AIR PANASDI NAGARI TALANG, KABUPATEN SOLOK DAN DI NAGARI PANTI, KABUPATEN PASAMAN, SUMATERA BARAT

Ardian Putra, Rahmatul Hidayat, Rahmat Arrahman 459

PENENTUAN SUSEPTIBILITAS DAN DERAJAT ANISOTROPI M AGNETIK SAM PEL BIJIH BESI DARI KABUPATEN SOLOK SELATAN SUM ATERA BARAT

Arif Budiman, Hendry Gunawan, Alwis Abbas. .465

SIFAT M AGNET DAN STRUKTUR NANOPARTIKEL M AGNETIK DARI BATUAN BESI DISINTESIS DENGAN METODE KOPRESIPITASI-SONIKASI

Astuti, Betti Delmifiana 472

KAJIAN SIFAT MAGNET FERIT NIKEL ZINK $\left(\mathrm{Ni}_{1-x} \mathrm{Zn}_{x} \mathrm{Fe}_{2} \mathrm{O}_{4}\right)$ DENGAN M ETODE KOPRESIPITASI

Dwi Puryanti, M erry Thressia, Sri Handani. 481

KOM PUTASI NUM ERIK PARAM ETER KISI KRISTAL BERSTRUKTUR HEXAGONAL BERDASARKAN POLA DIFRAKSI ELEKTRON DENGAN SUBROUTINE BISECTION

Erwin, Salomo, Defrianto, M bantun Ginting dan M. Rasyid Ridho. 486

ANALISIS BURN UP PADA REAKTOR CEPAT BERPENDINGIN GAS M ENGGUNAKAN BAHAN BAKAR URANIUM ALAM

Feriska Handayani Irka, Zaki Su'ud 496

UJI SIFAT TERM AL POHON ACACIA M ANGIUM 
Irzaman, Ana Fitriana, TantanTaopik Rahman, Riani Eka Fitri, Irlian Nurmaniah, Febrian Vernando, Nadia Septiani, Della Tiaraputri Aldrifisia, Fitrah Hadi Firdaus, Hadyan Akbar .503

KARAKTERISASI DAN PENUM BUHAN NANOPARTIKEL ZINK-OXIDE (ZnO) DI ATAS SUBSTRAT PADAT DENGAN METODE HIDROTERMAL

Iwantono, Elvi Oktorina, Erman Taer, dan Rika Taslim

SEL SURYA FOTOELEKTROKIMIA DENGAN NANOPARTIKEL ZnO SEBAGAI M ATERIAL AKTIF

ELEKTRODA KERIA DAN NANOPARTIKEL PLATINUM SEBAGAI ELEKTRODA LAWAN

Iwantono, Fera Anggelina, Erman Taer, dan Rika Taslim. 518

PENUM BUHAN DAN KARAKTERISASI NANOPARTIKEL ZnO PADA SUBSTRAT PADAT DENGAN METODE SEED M EDIATED GROWTH

Iwantono, Winda Nurwidya Erman Taer, dan Rika Taslim.... .525

VARIASI STRUKTUR M IKRO HUJAN DI SEPANJANG EKUATOR INDONESIA

Marzuki, H. Hashiguchi, M. K. Yamamoto, Shuichi M ori, Yukihiro Takahashi.

ANALISIS DIAM ETER BIOPELET SEKAM PADI TERHADAP EFISIENSI ENERGI BAHAN BAKAR

Masitoh, Mersi Kurniati, Irzaman 540

POLA DISTRIBUSI FLUKS NEUTRON DALAM SEL BAHAN BAKAR NUKLIR DI SETIAP REGIONNYA DENGAN METODE COLLISION PROBABILITY

Mohammad Ali Shafii..... .549

ANALISIS ELECTRON SPIN RESONANCE PADA PROSES PENCAIRAN BATUBARA MUDA DENGAN PELARUT SHORT RESIDUE

Muhammad Sahal .557

UJI KARAKTERISTIK SENSITIVITAS SENSOR CAHAYA TERHADAP VARIASI JARAK

Rahmat Rasyid, Wildian, Wendri 564

PEM BUATAN PROTOTIPE M EKANIK UNTUK KAM ERA BERBASIS Ba $\mathrm{B}_{0,5} \mathrm{Sr}_{4,5} \mathrm{TiO}_{3}$

Reza Fahmi Hidayat, Iwan Kurnia, Indra Purnomo, Zaidah Rifah Uswatun, Ade Kurniawan, Johan Iskandar, Ardian Arif, Irzaman .....

KARAKTERISASI KARBON AKTIF KAYU BAKAU DENGAN AKTIVASI TERM AL SEBAGAI FILTER PENJERNIH AIR SUNGAI TAM IANG

Susilawati Tulus Ikhsan Nasution. 579

VARIABILITAS CURAH HUJAN DAN PENGARUHNYA TERHADAP REKOM ENDASI ITU-R: STUDI KASUS CURAH HUJAN DI KOTO TABANG

Triana Vitri, M arzuki..... 589

PENGARUH UKURAN BUTIRAN TERHADAP SIFAT-SIFAT M AGNET ALLOY FeSi

Zulkarnain, Djoko Triyono .598

PEM ETAAN DAN PENGUKURAN RISIKO BAHAYA KESEHATAN LINGKUNGAN KERJA KILANG PT PERTAM INA RU II DUMAI

xii 
Dr.M uhammad Edisar, MT.....

PENGEM BANGAN GENERIC LIFE SKILL SISWA SEKOLAH M ENENGAH PERTAM A PADA PEM BELAJARAN FISIKA

Festiyed 617

PEM ODELAN LALU LINTAS BERDASARKAN PRINSIP ACTIVE WALKER

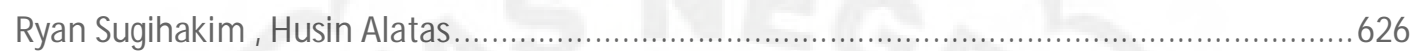
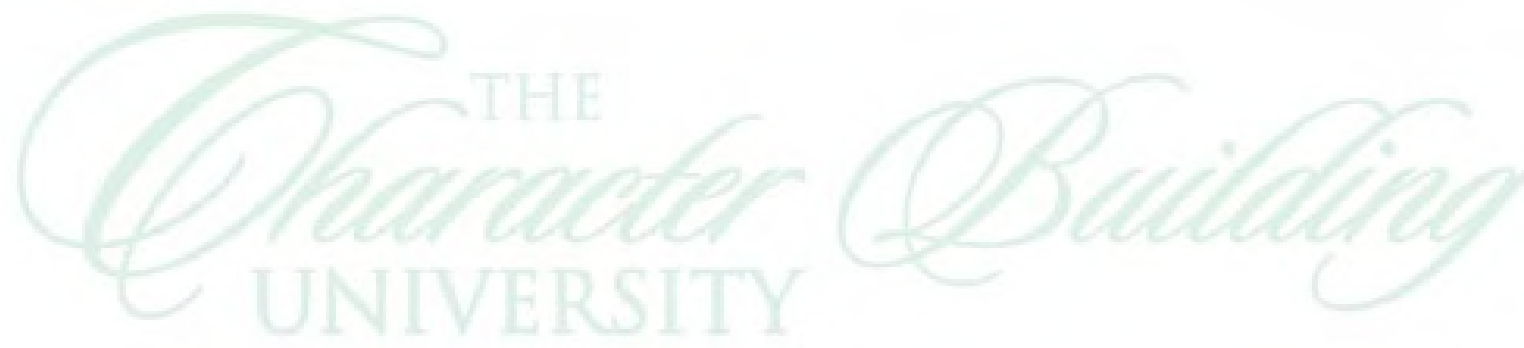


\section{INTEGRASI}

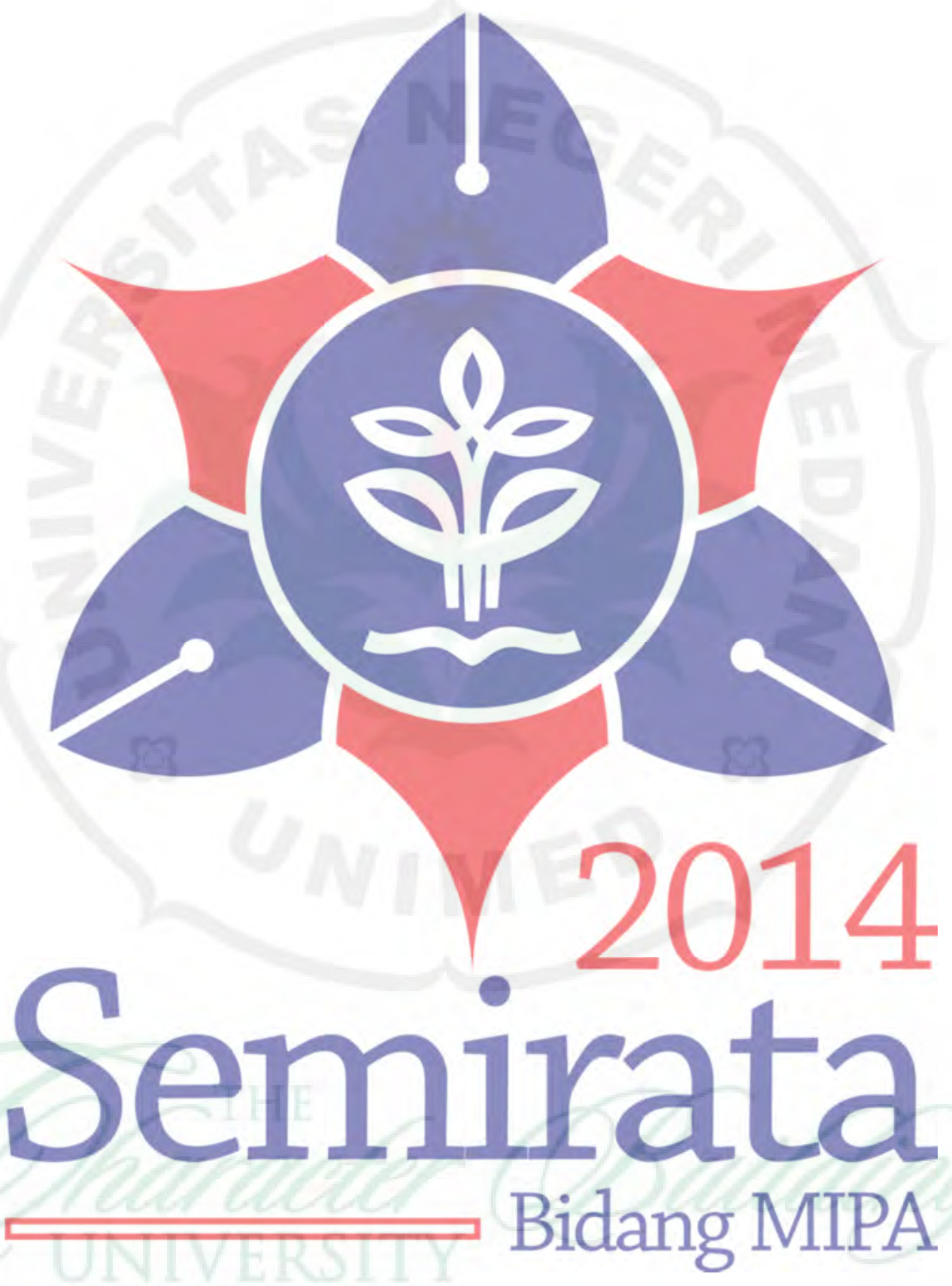




\title{
HASIL VALIDASI BAHAN AJAR ICT SAINS TERPADU MODEL TERHUBUNG MENGINTEGRASIKAN NILAI KARAKTER UNTUK PEMBELAJARAN SISWA SMP KELAS VIII
}

\author{
VALIDATION RESULT OF SCIENCE ICT LEARNING MATERIAL USES \\ CONNECTED MODEL BY INTEGRATING THE CHARACTER VALUES \\ TO STUDENTS LEARNING IN JUNIOR HIGH SCHOOL GRADE VIII
}

\author{
Asrizal $^{(1)}$, Ramadhan Sumarmin ${ }^{(2)}$, Iswendi ${ }^{(3)}$, dan Trisya Gustiya ${ }^{(4)}$ \\ (1) Jurusan Fisika,FMIPA Universitas Negeri Padang, Padang (asrizal_unp@yahoo.com), \\ (2) Jurusan Biologi, FMIPA, Universitas Negeri Padañ \\ (3) Jurusan Kimia, FMIPA, Universitas Negeri Padang \\ (4) Mahasiswa Program Studi Pendidikan Fisika, FMIPA, Universitas Negeri Padang
}

\begin{abstract}
Integration among of science branches, ICT, and character values in learning process is necessary conducted in Junior High School. Science learning in Junior High School should be conducted because Science is an unity. Fact shows that Science in Junior High School is still separated. Purpose of this research is to produce a ICT learning material of integrated Science and to determine its validity result. This result can be categorized into research and development. There are five stages of this research, those are: to know potency and problem, to collect the information, to design the ICT learning material, and to valid the ICT learning material. Base on the development of ICT learning material can be stated two results of this research. First. Main menus of integrated Science learning material consist of home, identities, competency, introduction, learning material, exercise, competency test, references, and supporting menus. Second, validity result of integrated Science learning material is very good with average value is 85.90 .
\end{abstract}

Keywords: Integration, Science, Integrated Science, ICT, Character Values

\begin{abstract}
ABSTRAK
Integrasi antara bidang IPA, ICT, dan nilai karakter proses pembelajaran penting dilakukan di SMP. Pembelajaran Sains di SMP seharusnya dilakukan secara terpadu karena pada dasarnya alam merupakan satu kesatuan. Fakta menunjukkan bahwa Sains di SMP masih terpisah-pisah. Tujuan dari penelitian adalah untuk menghasilkan suatu bahan ajar ICT Sains terpadu dan menentukan hasil validasinya. Penelian yang dilakukan dapat dikelompokkan ke dalam penelitian dan pengembangan yaitu suatu penelitian yang menghasilkan produk tertentu dan menguji efektivitas dari produk tersebut. Ada lima langkah penelitian yang telah diterapkan yaitu: mengenal potensi dan masalah, mengumpulkan informasi, dan mendesain produk bahan ajar, dan memvalidasi produk. Berdasarkan desain pengembangan produk bahan ajar Sains terpadu berbasis ICT dapat dikemukan dua hasil dari penelitian ini. Pertama, menu utama bahan ajar Sains terpadu berbasis ICT mengintegrasikan nilai karakter terdiri dari home, identitas, kompetensi, pendahuluan, materi pembelajaran, latihan soal, uji kompetensi, referensi dan menu pendukung. Kedua, nilai rata-rata validitas dari komponen substansi materi, desain pembelajaran, tampilan media komunikasi, dan penggunaan software adalah 85.9 yang berada pada kategori sangat baik.
\end{abstract}

Kata Kunci: Integrasi, Sains, Sains Terpadu, ICT, Nilai Karakter

\section{PENDAHULUAN}

Pendidikan Sains memiliki peranan penting dalam menyiapkan peserta didik untuk memasuki dunia kehidupannya. Sesuai dengan karakteristiknya, pendidikan Sains memiliki potensi dan peranan strategis dalam menyiapkan SDM yang berkualitas untuk menghadapi era globalisasi (Dede TK : 2013). Potensi ini dapat diwujudkan jika pendidikan Sains mampu menghasilkan peserta didik yang memiliki keterampilan proses Sains, memiliki sikap ilmiah, dan menerapkannya dalam kehidupan. Beberapa 
keterampilan Sains seperti berpikir logis, berpikir kreatif, kemampuan memecahkan masalah, bersifat kritis, menguasai teknologi, dan kemampuan beradaptasi sangat penting dalam kehidupan.

Penerapan pembelajaran yang berkualitas merupakan suatu faktor penentu keberhasilan pendidikan Sains. Melalui pembelajaran Sains peserta didik dapat mengkonstruksi pengetahuan tentang gejala alam melalui proses Sains. Dengan proses Sains yang baik, peserta didik dapat mengembangkan sikap ilmiah seperti ingin tahu, kritis, jujur, terbuka, objektif, tekun, dan sebagainya. Sikap ilmiah yang dikembangkan melalui proses Sains tidak lain adalah bagian nilai karakter dalam pendidikan.

Pada hakikatnya pembelajaran Sains dilakukan secara terpadu. Alasannya adalah semua fenomena alam tidak dapat dipelajari secara terpisah-pisah. Sains merupakan suatu ilmu yang mempelajari gejala-gejala alam. Alam biasanya mengenalkan dirinya sebagai satu kesatuan dan bukan terpisah-pisah. Sebagai contoh air adalah bagian dari alam yang tidak bisa hanya dilihat dari segi Fisika, Kimia, atau Biologi, tetapi merupakan kesatuan air dengan segala kandungan dan sifat-sifatya (Das S : 2009).

Pembelajaran terpadu merupakan pendekatan pembelajaran yang secara sengaja mengaitkan beberapa aspek baik dalam intra mata pelajaran maupun antar mata pelajaran. Dengan keterpaduan siswa memperoleh pengetahuan dan keterampilan secara utuh sehingga pembelajaran menjadi bermakna. Bermakna berarti siswa dapat memahami konsep-konsep yang dipelajari melalui pengalaman langsung yang menghubungkan antar konsep dalam intra mata pelajaran maupun antar mata pelajaran.

Banyak alternatif yang dapat dilakukan untuk mengintegrasikan bidang ilmu Sains dalam suatu model pembelajaran terpadu. Secara umum menurut Robin F ada sepuluh model pembelajaran terpadu yaitu: keterkaitan (connected), terpisah (fragmented), terkumpul (nested), terurut (sequenced), terbagi (shared), terulir (threaded), terselaput laba-laba (webbed), terbenam (immersed), terjaring (networked), dan terintegrasi (integrated) (Hepta J: 2012). Pemilihan model pembelajaran terpadu tergantung kepada keterkaitan antara satu kompetensi dengan kompetensi lainnya dalam bidang Sains.

Pembelajaran terpadu model keterkaitan adalah salah satu model pembelajaran terpadu yang menghubungkan satu konsep dengan konsep lain, satu topik dengan topik lain, satu keterampilan dengan keterampilan lainnya, satu tugas dengan tugas lainnya, dan satu ide dengan ide lainnya dalam satu bidang studi (Siti S: 2008). Dengan cara seperti ini, satu bidang Sains dalam suatu mata pelajaran saling terkait antara satu bidang dengan bidang yang lainnya. Model pembelajaran ini menyajikan hubungan yang nyata di dalam suatu mata pelajaran dengan cara menghubungkan satu topik dengan topik yang 
lain, satu konsep ke konsep yang lain, satu keterampilan dengan keterampilan yang lain, atau satu tugas ke tugas yang lain (Bambang I : 2011).

Model pembelajaran Sains terpadu direkomendasikan di tingkatan SMP, karena ternyata memiliki beberapa tujuan yaitu: meningkatkan efesiensi dan efektivitas pembelajaran, meningkatkan minat dan motivasi, dan beberapa kompetensi dasar dapat dicapai sekaligus. Keunggulan pembelajaran Sains terpadu: efisien dan efektif, materimateri tidak saling tumpang tindih antara satu dengan yang lain. Selain itu, waktu pembelajaran dapat dihemat untuk kegiatan lapangan, meningkatkan minat dan motivasi, mempermudah dan memotivasi siswa untuk memahami konsep pengetahuan secara menyeluruh. Model pembelajaran sains terpadu dapat menghemat waktu, tenaga dan sarana, dan biaya pendidikan (Ari G: 2011).

Melalui pembelajaran Sains terpadu, siswa dapat memperoleh pengalaman langsung, sehingga dapat menambah kekuatan untuk menerima, menyimpan, dan menerapkan konsep yang telah dipelajarinya. Siswa terlatih untuk menemukan sendiri berbagai konsep yang dipelajari secara menyeluruh, bermakna, autentik dan aktif. (Nurrany: 2011). Pencapaian keutuhan belajar Sains, kebulatan pandangan tentang kehidupan, dunia nyata dan fenomena alam hanya dapat direfleksikan melalui pembelajaran terpadu.

Dari segi ilmu psikologi dan pendidikan, seorang siswa akan lebih mudah mengenal dan memahami benda-benda di alam secara keseluruhan terlebih dahulu dan bukan melalui bagian-bagiannya yang terkecil. Pembelajaran Sains terpadu sangat sesuai diterapkan untuk siswa SMP dibandingkan jika diberikan secara terpisah. Pembelajaran Sains terpadu dipercaya lebih mampu menumbuhkan kreativitas siswa dan lebih menyenangkan sehingga sesuai dengan tuntutan standar proses.

Berdasarkan hasil pengamatan peneliti pada kegiatan pembinaan guru dan siswa di Sumatera Barat ternyata pelaksanaan pembelajaran Sains di SMP dilakukan secara terpisah-pisah. Pada umumnya kompetensi yang berhubungan dengan materi biologi diajarkan oleh guru biologi, kompetensi yang berhubungan dengan materi fisika diajarkan oleh guru fisika. Disisi lain kompetensi yang berhubungan dengan materi kimia diajarkan oleh guru fisika atau guru biologi. Dengan cara seperti ini mata pelajaran IPA di SMP dikenal dengan IPA Fisika, IPA Biologi, dan IPA Kimia.

Dengan penerapan pembelajaran Sains secara terpisah-pisah menyebabkan penguasaan siswa terhadap Sains menjadi rendah. Fakta ini diperkuat oleh hasil studi PISA tahun 2009 yang menunjukkan bahwa Indonesia berada pada peringkat ke 60 dari 65 negara peserta dengan skor 385 untuk bidang Sains yang mencakup Fisika, Kimia, 
dan Biologi. Peringkat Indonesia berada jauh dibawah Singapura yang berada pada peringkat ke 4 dengan skor 542 (Nugraheni D: 2012).

Upaya untuk mengatasi permasalahan ini perlu dilakukan. Sebagai alternatif solusi untuk mengatasi permasalahan ini adalah mengembangkan bahan ajar Sains terpadu berbasis ICT dengan mengintegrasikan nilai karakter. Hal ini sesuai dengan rancangan kurikulum 2013 yang menyatakan bahwa proses pembelajaran IPA dan IPS masingmasing diajarkan secara terpadu. IPA dikembangkan sebagai mata pelajaran ilmu alam terintegrasi, bukan sebagai pendidikan disiplin ilmu. Pendidikan Sains berorientasi aplikatif, pengembangan kemampuan berpikir, kemampuan belajar, rasa ingin tahu, dan pembangunan sikap peduli dan bertanggung jawab terhadap lingkungan alam. Dengan alasan ini maka pengembangan bahan ajar Sains terpadu perlu dilakukan.

Bahan ajar merupakan bagian yang penting dalam pembelajaran karena dapat digunakan sebagai sumber belajar baik bagi guru maupun siswa. Bahan ajar adalah seperangkat materi yang disusun secara sistematis baik tertulis maupun tidak sehingga tercipta suasana yang memungkinkan siswa untuk belajar (Bambang S: 2007). Disisi lain bahan ajar merupakan suatu komponen sistem pembelajaran yang memegang peranan penting dalam membantu siswa mencapai kompetensi dasar dan standar kompetensi. Secara garis besar, bahan ajar berisi pengetahuan, keterampilan, dan sikap atau nilai yang harus dipelajari siswa (Abdul G: 2004).

Bahan ajar berbasis ICT merupakan bahan ajar yang disusun dan dikembangkan dengan menggunakan alat bantu ICT untuk mengolah data meliputi: memproses, mendapatkan, menyusun, menyimpan, dan memanipulasi data dalam berbagai cara untuk menghasilkan sumber informasi yang berkualitas (Sungkowo: 2010). Ada tiga karakteristik dari bahan ajar berbasis ICT yaitu menyajikan multimedia; menyimpan, mengolah, menyajikan informasi, dan memanfaatkan hyperlink (Lu'mu T: 2011). Dengan adanya karakteristik ini, membuat bahan ajar berbasis ICT menjadi unggul. Secara umum bahan ajar berbasis ICT terdiri dari halaman muka, kompetensi, indikator pencapaian, materi pembelajaran, latihan soal, uji kompetensi, dan referensi (Sungkowo: 2010).

Pendidikan karakter dapat diintegrasikan dalam pembelajaran pada setiap mata pelajaran. Materi pembelajaran yang berkaitan dengan norma atau nilai-nilai pada setiap mata pelajaran perlu dikembangkan, dieksplisitkan, dikaitkan dengan konteks kehidupan sehari-hari. Dengan demikian, pembelajaran nilai-nilai karakter tidak hanya pada tataran kognitif, tetapi menyentuh pada internalisasi, dan pengamalan nyata dalam kehidupan peserta didik sehari-hari di masyarakat (Akhmad S: 2010).

Integrasi nilai pendidikan karakter dapat dilakukan kedalam pembelajaran untuk membentuk karakter siswa. Pengintegrasian nilai-nilai karakter bangsa kedalam kegiatan 
pembelajaran berarti memadukan, memasukkan, dan menerapkan nilai-nilai yang diyakini baik dan benar dalam rangka membentuk, mengembangkan, dan membina tabiat atau kepribadian peserta didik sesuai jatidiri bangsa tatkala kegiatan pembelajaran berlangsung. Integrasi nilai-nilai karakter bangsa pada kegiatan pembelajaran dapat dilakukan melalui tahap-tahap: perencanaan, pelaksanaan, dan evaluasi (Anik G: 2009).

Dari latar belakang masalah yang telah diuraikan dapat dirumuskan masalah dalam penelitian ini. Sebagai perumusan masalah dari penelitian ini yaitu: Bagaimana deskripsi dan validitas dari bahan ajar Sains terpadu berbasis ICT dengan mengintegrasikan nilai karakter untuk pembelajaran siswa SMP ?. Tujuan dari penelitian ini adalah untuk mendeskripsikan bahan ajar Sains terpadu berbasis ICT mengintegrasikan nilai karakter dan menentukan validitasnya.

\section{METODE PENELITIAN}

Jenis penelitian yang akan dilakukan adalah Research and Development (R\&D). R\&D adalah metode penelitian yang digunakan untuk menghasilkan produk tertentu, dan menguji keefektifan produk tersebut (Sugiyono: 2006). Disisi lain R\&D adalah suatu proses atau langkah-langkah untuk mengembangkan suatu produk baru atau menyempurnakan produk yang telah ada, yang dapat dipertanggung jawabkan (Nana S S: 2006). Berarti produk merupakan bagian yang penting pada penelitian ini.

Kegiatan penelitian diarahkan untuk mengembangkan bahan ajar Sains terpadu berbasis ICT dengan mengintegrasikan nilai karakter yang memiliki deskripsi dan validitas yang baik. Pada tahap ini dilakukan lima langkah dari penelitian dan pengembangan yaitu: mengenal potensi dan masalah, mengumpulkan informasi, mendesain produk, memvalidasi desain, dan memperbaiki desain.

a. Mengenal Potensi dan Masalah

Potensi merupakan peluang dapat terjadinya sesuatu peristiwa. Implementasi kurikulum 2013 memberikan peluang dalam pengembangan bahan ajar Sains terpadu. Kurikulum 2013 mendorong adanya integrasi suatu ilmu dengan ilmu lainnya terutama di tingkat SD dan SMP, integrasi ICT kedalam suatu mata pelajaran, dan integrasi nilai karakter dalam pendidikan. Dengan adanya kompetensi inti spiritual dan kompetensi inti spiritual dalam kurikulum 2013 memberikan kemudahan dalam mengintegrasikan nilai karakter kedalam bahan ajar. Kompetensi siswa secara utuh mencakup pengetahuan, sikap, dan keterampilan dibentuk pada kegiatan inti dalam standar proses.

Dalam pengembangan bahan ajar Sains terpadu berbasis ICT mengintegrasikan nilai karakter dihadapkan pada beberapa permasalahan. Permasalahan pertama, guru IPA di SMP terutama di Sumatera Barat belum terbiasa menerapkan pembelajaran Sains terpadu. Pembelajaran Sains selama ini masih dilakukan secara terpisah-pisah. 
Permasalahan kedua, masih banyak guru di SMP yang beranggapan sebagai guru Fisika dan guru Biologi. Padahal mata pelajaran yang ada di SMP adalah IPA. Permasalahan ketiga adalah implementasi kurikulum 2013 baru untuk kelas VII di SMP untuk beberapa mata pelajaran. Guru IPA SMP kelas VIII banyak yang belum bersedia menerapkan pembelajaran Sains terpadu, padahal pendekatan ini sudah dituntut dalam KTSP.

b. Mengumpulkan Informasi

Informasi merupakan bagian yang penting dalam mengembangkan suatu ide penelitian. Dalam pengembangan bahan ajar Sains terpadu berbasis ICT dengan mengintegrasikan nilai karakter ini diperoleh informasi dari diskusi dengan guru IPA SMP, supervisi pembelajaran, internet, dan kegiatan ilmiah. Dari hasil diskusi dengan guru IPA dan supervisi pembelajaran didapat beberapa informasi seperti guru sudah mulai menerapkan ICT dan karakter dalam pembelajaran. Dari referensi yang didapat di internet terutama implementasi kurikulum 2013 mendorong adanya integrasi dalam pembelajaran seperti keterkaitan dengan bidang ilmu lain, nilai karakter, dan ICT. Melaui kegiatan ilmiah seperti konasfi dan forum MIPA diperoleh informasi antara lain: pentingnya pembentukan nilai karakter bagi generasi muda melalui pendidikan, pembentukan kompetensi siswa secara utuh, dan relevansi kompetensi siswa dengan tuntutan era globalisasi.

c. Mendesain Produk

Desain bahan ajar Sains terpadu berbasis ICT dengan mengintegrasikan nilai karakter dimulai dengan melakukan analisis standar kompetensi dan kompetensi dasar, mengembangkan indikator pencapaian kompetensi, mengembangkan materi pembelajaran, dan mengembangkan bahan ajar. Menu utama bahan ajar Sains terpadu terdiri dari: identitas, pendahuluan, materi pembelajaran, latihan, evaluasi, dan referensi. Bahan ajar ini dikembangkan menggunakan software moodle.

d. Memvalidasi Desain

Desain produk bahan ajar Sains terpadu yang sudah dibuat perlu divalidasi. Tujuan uji validasi desain produk adalah untuk menilai bahan ajar Sains terpadu efektif menurut pemikiran rasional. Penilaian validasi desain produk dilakukan oleh lima orang ahli yang menguasai pengetahuan dasar sains, media pembelajaran, dan pemanfaatan internet sebagai sumber belajar.

e. Memperbaiki Desain

Uji validasi desain produk bahan ajar Sains terpadu menggunakan lembar uji validasi. Lembar uji ini disusun menggunakan kriteria penilaian bahan ajar berbasis ICT. Dalam lembar uji ini tenaga ahli memberikan penilaian, tanggapan, dan masukan. Berdasarkan tanggapan dan masukan dari tenaga ahli dilakukan perbaikan terhadap desain produk untuk menghasilkan produk bahan ajar Sains terpadu yang lebih baik. 
Instrumen pengumpul data yang digunakan lembar uji validitas. Lembar ini digunakan untuk mengetahui tingkat validitas bahan ajar Sains terpadu berbasis ICT menurut pemikiran rasional dari tenaga ahli. Instrumen uji validitas bahan ajar disusun berdasarkan penilaian bahan ajar berbasis ICT dengan empat indikator yaitu: substansi materi, tampilan komunikasi visual, desain pembelajaran, dan pemanfaatan software.

Analisis produk dan data yang digunakan adalah metoda mendeskripsikan dan metoda grafik. Metoda mendeskripsikan digunakan untuk mendeskripsikan produk dalam bentuk bahan ajar Sains terpadu berbasis ICT dengan mengintegrasikan nilai karakter. Disisi lain metoda grafik digunakan untuk menentukan nilai validitas untuk setiap indikator penilaian bahan ajar berbasis ICT dengan mengintegrasikan nilai karakter.

\section{HASIL DAN PEMBAHASAN}

a. Deskripsi Bahan Ajar Sains Terpadu Berbasis ICT Mengintegrasikan Nilai Karakter

Produk bahan ajar sains terpadu disusun berdasarkan standar kompetensi, kompetensi dasar, indikator, dan tujuan pembelajaran Sains kelas VIII di SMP. Penyusunan bahan ajar Sains terpadu berdasarkan format bahan ajar berbasis ICT. Dalam perangkat pembelajaran Sains terpadu, bahan ajar merupakan salah satu bagian yang dapat digunakan oleh guru dan siswa dalam pembelajaran. Tampilan bahan ajar Sains terpadu dalam perangkat pembelajaran diperlihatkan pada Gambar 1

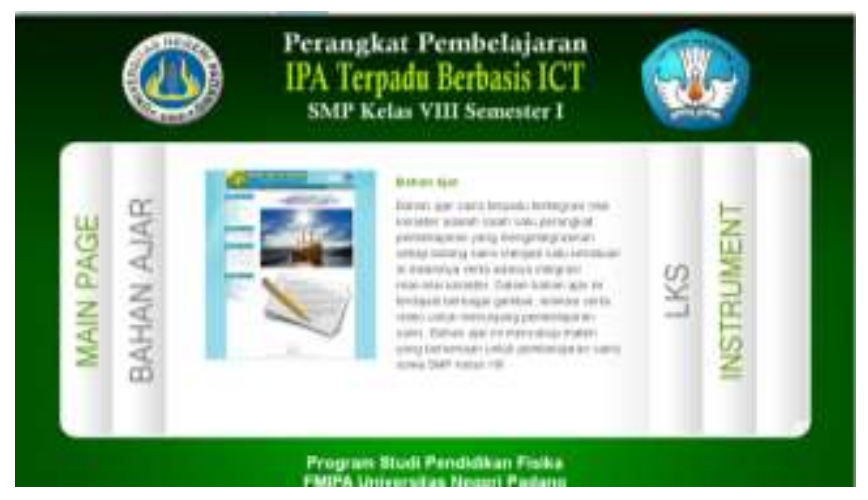

Gambar 1. Tampilan Bahan Ajar Sains Terpadu Berbasis ICT

Pada tampilan bahan ajar ini, pengguna diberi informasi tentang bahan ajar sains terpadu, sifat dari bahan ajar, kelebihan dari bahan ajar, dan cakupan materi pembelajaran dalam bahan ajar. Sifat dari bahan ajar adalah adanya integrasi nilai karakter cerdas dalam bahan ajar. Integrasi nilai karakter dilakukan melalui tiga cara yaitu: informasi, instruksi, dan analogi pada bahan ajar. Kelebihan bahan ajar Sains terpadu adalah penggunaan komponen multimedia dalam bahan ajar seperti gambar, video, dan animasi sehingga membuat bahan ajar menjadi interaktif yang sesuai dengan kompetensi yang dibahas. 
Apabila pengguna mengklik bahan ajar pada judul, maka pengguna masuk pada halaman utama bahan ajar sains terpadu. Halaman utama bahan ajar ini terdiri atas banner, usename, main menu, gambar dan kata pengenalan tentang bahan ajar secara singkat. Tampilan halaman utama dan menu utama dari bahan ajar sains terpadu diperlihatkan pada Gambar 2 :

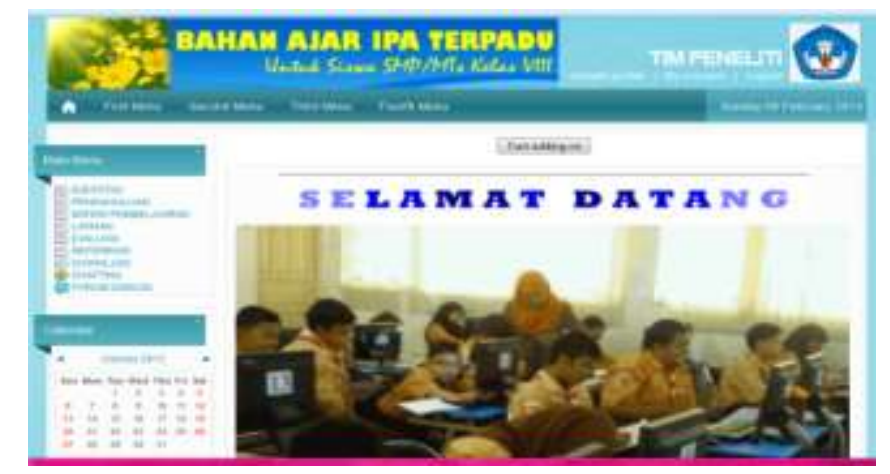

Gambar 2. Tampilan Halaman Utama Bahan Ajar Sains

Halaman utama bahan ajar merupakan bagian penting dalam bahan ajar karena pengguna dapat mengetahui bagian-bagian isi penting dari bahan ajar secara umum. Pada halaman utama bahan ajar berisi pilihan menu bahan ajar yang berfungsi sebagai navigasi sebagai penghubung antara menu utama dengan materi yang diinginkan. Hal ini memudahkan siswa dan guru dalam menggunakan bahan ajar sains terpadu berbasis ICT. Pilihan menu utama pada bahan ajar meliputi: home, identititas, pendahuluan, materi pembelajaran, latihan, evaluasi, download, chatting dan forum.

Pada bagian menu identitas diakses dengan mengklik pilihan main menu pada halaman utama. Menu indentifikasi memperkenalkan bahan ajar sains terpadu. Menu latihan berisi gambar, kelas, semester, penulis bahan ajar Sains terpadu berbasis ICT.

Menu pendahuluan terdiri atas tiga buah sub menu yaitu deskripsi bahan ajar, panduan bahan ajar dan kompetensi bahan ajar. Bagian deskripsi bahan ajar berisikan gambaran umum tentang bahan ajar. Panduan pada bahan ajar berisikan cara-cara menggunakan bahan ajar sains terpadu ini seperti log in, memilih menu dan sebagainya. Kompetensi bahan ajar berikan standar kompetensi dan kompetensi dasar yang terkait yang pada materi bahan ajar sains terpadu.

Menu materi berikan enam buah sub menu yang disusun berdasarkan standar kompetensi dan kompetensi dasar yang ada. Sub menu yang ada pada menu materi dapat diakses dengan mengklik tulisan atau gambar yang ada. Materi pembelajaran yang terdapat dalam bahan ajar ada enam yaitu: gerak lurus, gaya, hukum Newton, usaha dan energi, pesawat sederhana, dan tekanan.

Menu latihan disediakan sesuai banyaknya materi pembelajaran yaitu 6 buah. Setiap sub menu latihan terdiri atas soal pilihan dan soal essay. Soal dalam bentuk 
latihan terdiri atas dua macam. Bentuk pertama yaitu pilihan ganda dan bentuk kedua yaitu menjodohkan. Menu latihan merupakan usaha untuk memantapkan hasil belajar untuk siswa.

Menu evaluasi disediakan sesuai banyaknya materi pembelajaran yaitu 6 buah. Setiap sub menu evaluasi terdiri atas soal pilihan dan soal essay. Menu evaluasi hanya dapat di akses pada tanggal dan jam yang telah ditentukan. Melalui menu evaluasi ini dapat melihat sudah sejauh manakah penguasan siswa terhadap pembelajaran.

Menu referensi berisikan sumber-sumber yang digunakan dalam menyusun bahan ajar sains terpadu. Siswa yang ingin menambah pengetahuan lebih jauh lagi dapat mengakses sumber-sumber yang tertera pada bahan ajar. Daftar referensi ditulis sesuai dengan kaedah yang seharusnya.

Menu chatting diperlukan untuk membuat komunikasi antara siswa dengan guru atau antara siswa dengan siswa lainnya. Menu chatting dapat diakses dengan mengklik pilihan main menu yang ada pada halaman utama. Menu chat memfasilitasi siswa dengan siswa, ataupun siswa dengan guru untuk dapat saling berkomunikasi. Melalui menu ini memfasilitasi siswa dengan siswa maupun siswa dengan guru untuk berkomunikasi dimana saja dan kapan saja.

\section{b. Hasil Validitas Bahan Ajar Sains Terpadu Berbasis ICT}

Hasil dari instrumen validitas tenaga ahli digunakan untuk menentukan nilai validitas dari bahan ajar Sains terpadu dan pedoman dalam merevisi desain. Berdasarkan instrumen penilaian validitas tenaga ahli terhadap bahan ajar dianalisis empat komponen penilaian. Komponen penilaian yang digunakan adalah substansi materi, desain pembelajaran, tampilan komunikasi visual, dan pemanfaatan software. Uji validitas bahan ajar sains terpadu dilakukan oleh 5 orang dosen Fisika dengan bobot minimum adalah 5 dan bobot maksimum adalah 25. Bobot setiap indikator dikonversi ke dalam bentuk nilai berkisar antara 1-100 sehingga nilai terendah adalah 20 dan nilai tertinggi adalah 100 .

Pada indikator substansi materi terdapat delapan indikator yaitu: kesesuaian materi, cakupan materi, integrasi pada materi, kaitan materi dengan ilmu bidang lain, integrasi nilai karakter, penggunaan ICT, penggunaan kalimat, dan penggunaan paragraf. Nilai komponen subtansi materi yang terdiri dari delapan indikator berkisar antara 80 sampai 92. Nilai terendah berada pada indikator integrasi pada materi dan kaitan materi dengan ilmu bidang lain yaitu 80 . Nilai tertinggi yaitu 92 terdapat pada indiator kesesuaian materi dan cakupan materi. Nilai rata-rata pada komponen subtansi materi adalah 85,0.

Pada komponen desain pembelajaran terdapat delapan indikator yaitu: judul materi pembelajaran, indikator materi pembelajaran, materi pembelajaran, contoh soal pada 
bahan ajar, latihan pada bahan ajar, daftar rujukan, integrasi ilmu bidang lain pada materi, dan integrasi ilmu bidang lain pada latihan.

Nilai komponen desain pembelajaran yang terdiri dari delapan indikator berkisar antara 84 sampai 96 . Nilai tertinggi yaitu 96 terdapat pada indikator materi pembelajaran pada bahan ajar sains terpadu berbasis ICT mengintegrasikan nilai karakter. Nilai terendah yaitu 84 berada pada lima indikator diantaranya judul materi pembelajaran latihan pada bahan ajar, daftar rujukan, integrasi ilmu bidang lain, dan integrasi ilmu bidang lain pada latihan. Indikator materi pembelajaran dan contoh soal pada bahan ajar mendapat nilai 92. Berdasarkan data didapatkan nilai rata-rata pada komponen desain pembelajaran adalah 87,5.

Pada komponen validitas tampilan komunikasi visual terdapat enam komponen yaitu: tampilan navigasi, komposisi huruf, tampilan gambar dan video, komposisi warna, penggunaan animasi, dan desain layout. Nilai komponen tampilan komunikasi visual dalam bahan ajar berkisar antara 80 sampai 96 . Nilai validitas rata-rata pada komponen tampilan komunikasi visual adalah 87,3.

Pada komponen pemanfaatan software dari penilaian bahan ajar terdapat enam buah indikator yaitu: interaktivitas pada menu utama, interaktivitas pada menu latihan, interaktivitas pada menu evaluasi, software pendukung untuk menjalankan animasi, software pendukung untuk mengedit, dan keaslian hasil karya. Nilai komponen pemanfaatan software yang terdiri dari enam indikator berkisar antara 80 sampai 84 . Nilai tertinggi yaitu 84 terdapat pada indikator interaktivitas pada menu utama dan keaslian hasil karya. Nilai terendah berada pada indikator software pendukung untuk mengedit yaitu 76. Nilai rata-rata pada komponen pemanfaatan software adalah 81,3.

Dari keempat indikator penilaian bahan ajar sains terpadu mengintegrasikan nilai karakter didapatkan nilai rata-rata validitas. Nilai rata-rata subtansi materi, desain pembelajaran, tampilan media komunikasi, dan pemanfaatan software masing-masing 85,$0 ; 87,5 ; 87,3$; dan 81,3 . Hasil plot nilai rata-rata setiap indikator penilaian bahan ajar Sains terpadu terhadap indikator dapat diperhatikan pada Gambar 3

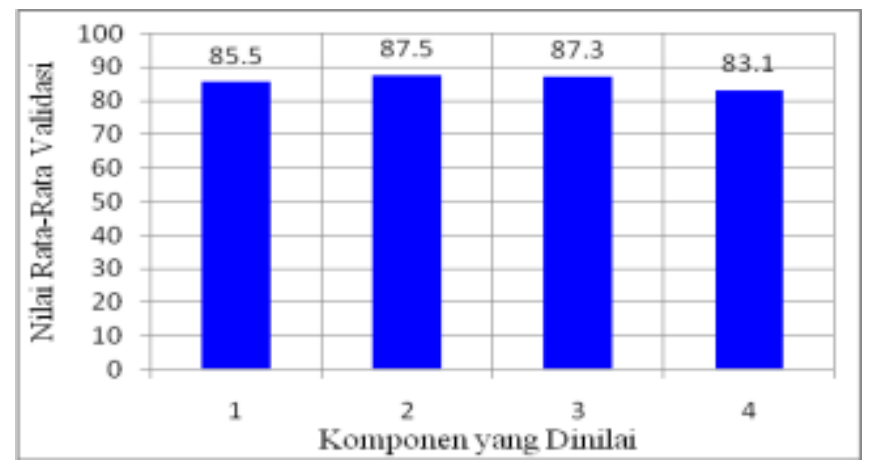

Gambar 3. Nilai Rata-Rata Hasil Uji Validitas Bahan Ajar Sains Terpadu 
Dari Gambar 3 dapat dikemukakan bahwa nilai rata-rata setiap komponen penilaian validitas berkisar antara 83,1 sampai 87,5 . Hal ini berarti nilai validitas dari komponen substansi materi, desain pembelajaran, tampilan media komunikasi, dan penggunaan software berada pada kategori sangat baik. Nilai rata-rata penilaian validitas bahan ajar sains terpadu berbasis ICT dengan mengintegrasikan nilai karakter adalah 85.9 yang berada pada kategori sangat baik.

\section{PUSTAKA}

[1] Abdul Gani. 2004. Pedoman Khusus Penyusunan Materi Pembelajaran (Instructional Materials). Direktoral Jenderal Pendidikan Dasar dan Menengah, Jakarta.

[2] Anik Gufron. 2009. Integrasi Nilai-Nilai Karakter Bangsa Pada Kegiatan Pembelajaran. Universitas Negeri Yogyakarta.

[3] Ari Gunawan. 2011. Pendidikan IPA Terpadu, Harus Bisa!. Kompasiana

[4] Bambang Indrianto. 2011. Panduan Pengintegrasian Nilai-Nilai ESD Dalam Pembelajaran. Pusat Penelitian Kebijakan Badan Penelitian dan Pengembangan Kementrian Pendidikan Nasional, Jakarta.

[5] Bambang S. 2007. Materi Sosialisasi dan pelatihan Kurikulum Tingkat Satuan Pendidikan (KTSP) SMA. Departemen Pendidikan Nasional, Jakarta.

[6] Das Salirawati. 2009. Pembelajaran Terpadu Untuk Mendukung Kreativitas Siswa. Jurusan Pendidikan Kimia FMIPA UNY

[7] Dede Trie Kurniawan. 2013. Model Pembelajaran Berbasis Masalah Berbantuan Website Interaktif Pada Konsep Fluida Statis Untuk Meningkatkan Keterampilan Proses Sains Siswa Kelas XI. Prosiding Seminar Kontribusi Fisika 2013, Bandung, Indonesia.

[8] Hepta Jayawardana. 2012. 10 Model Pembelajaran Sains Terpadu Robin Forgaty. Hepta Biologi.

[9] Lu'mu Tasri. 2011. Pengembangan Bahan ajar Berbasis Web. Jurusan PendidikanTeknik Elektronika Fakultas Teknik UNM, Jurnal MEDTEK, Volume 3, Nomor 2, Oktober 2011

[10] Nana S S. 2000. Metode Penelitian Pendidikan. Program Pascasarjana Universitas Pendidikan Indonesia dan PT Remaja Rosdakarya.

[11] Nugraheni Dini. 2012. Pengembangan Kurikulum Kimia R SMA BI Menggunakan Kurikulum Rujukan Dari Singapura. S2 Thesis, Universitas Negeri Yogyakarta.

[12] Nurrany. 2011. Model Pembelajaran IPA Terpadu. Dunia Pendidikan Fisika.

[13] Siti Sriyati. 2008. Integrated Approach. Fakultas Pendidikan Matematika dan IImu Pengetahuan Alam. Universitas Pendidikan Indonesia

[14] Sugiyono. 2006. Metode Penelitian Pendidikan: Pendekatan Kuantitatif, Kualitatif, dan R\&D. Alfabeta, Bandung. 